\title{
Rola i zasadność społecznej odpowiedzialności biznesu w warunkach integracji europejskiej
}

Integracja europejska jest procesem ciagłym. Nie można powiedzieć, że jesteśmy w jakiejś jego konkretnej fazie, bez podania osiagnięć wskazujących na jej istnienie. Można zaryzykować twierdzenie, że z jednej strony integracja europejska jest procesem ciagłego zmierzania poszczególnych państw należących do wspólnoty unijnej do pełnego zintegrowania w zakresie społecznym, politycznym i gospodarczym, a z drugiej strony - procesem dostosowywania lokalnych gospodarek państw spoza Unii, zgłaszających akces do pełnego uczestnictwa w jej strukturach. Zatem proces integracji, poza wskazanymi płaszczyznami, odbywa się jakby dwutorowo: jest procesem ujednolicenia systemów wewnątrz Unii oraz dostosowywaniem gospodarek państw aspirujących do wejścia w jej obręb.

Próby zbliżenia systemów obowiązujących w poszczególnych państwach do wspólnej i spójnej polityki napotykają na różne przeszkody, spośród których na szczególną uwagę zasługują problemy wynikające z różnic kulturowych, mentalnych, historycznych, religijnych i politycznych. Ich przezwyciężanie następuje w drodze mozolnego i długiego dyskursu społecznego, podczas którego dokonuje się wspólna wymiana doświadczeń. Towarzyszy mu atmosfera dialogu. Niekiedy wymiana myśli odbywa się w formule konfrontacji, nie służącej ani nawiązaniu dialogu, ani osiągnięciu konsensusu (znawcy technik negocjacyjnych taką atmosferę określiliby zapewne mianem negocjacji twardych). Wspomniana sytuacja najczęściej ma miejsce wówczas, gdy rzecz idzie o pryncypia. W tym wypadku żadna ze stron nie chce ustąpić ze stanowiska, bowiem chodzi o wartości, których przestrzega i chce im pozostać wierna. Najbardziej spektakularnymi przykładami sporów o wartości są m.in. problematyczność formuły preambuły traktatu konstytucyjnego ${ }^{1}$, jak też niektóre zapisy traktatu lizbońskiego. W sporach dotyczących wartości trudno o wypracowanie takiego systemu w ramach polityki unijnej, na który bez zastrzeżeń zgodziłoby się każde państwo. Dlatego ważne jest poszukiwanie neutralnych przestrzeni życia społecznego, wokół których można osiągnąć szerszy konsensus społeczny. W moim przekonaniu taką sferą jest dziś biznes.

Mówiąc o uwarunkowaniach gospodarczych świata biznesu nie wolno pominąc problemów wynikających z procesu globalizacji. Jeśli mówimy o integracji europejskiej, pamiętać należy, że także Europa dziś się globalizuje. Procesy integracji i globalizacji zachodzą paralelnie. Zwolennicy globalizacji, wskazując na czynniki pozytywne tego procesu, którym nie sposób zaprzeczyć, pomijają fakt, że - paradoksalnie - ujednolicając płaszczyznę technologiczną, społeczną, polityczną, kulturową i ekologiczna, proces ten przyczynia się skutecznie do wzrostu procesu dezintegracji, np. w sensie przestrzennym. Mówiąc językiem Zygmunta

\footnotetext{
${ }^{1}$ Chodzi o zapis mówiący o europejskim dziedzictwie kulturowym, religijnym i humanistycznym. Nie ma w nim odwołania do wartości chrześcijańskich, czego domagał się wielokrotnie rząd Polski.
} 
Baumana, globalizacja zarazem jednoczy, jak i dzieli: „,...] skutki procesów globalizacyjnych nie wskazują powszechnie zakładanej jednorodności. Stosunek do czasu i przestrzeni jest bardzo zróżnicowany i różnicujący zarazem. Globalizacja w równym stopniu dzieli i jednoczy, a przyczyny podziału świata są takie same jak czynniki pobudzające do jego uniformizacji” (Bauman 2000, s. 6). Proces integracji, który niewątpliwie ma miejsce, przy pewnej interpretacji staje się co najmniej problematyczny. Z tego między innymi powodu należy poszukiwać względnie neutralnych przestrzeni życia społecznego, w których nabrałby on wyrazistszego charakteru i nie był obciążony bagażem różnych (tu odmiennych) doświadczeń kulturowych, religijnych czy historycznych, stanowiących, jak się okazuje, skuteczną przeszkodę do budowania jedności społecznej.

Chociaż nauki ekonomiczne również opierają się na pewnych wartościach, biznes, mimo że niekiedy uwikłany w zależności polityczne i funkcjonujący pod ich wpływem, na skutek większej świadomości etycznej menedżerów i kadry wyższego szczebla, może stać się terenem, na którym łatwiej będzie zbudować konsensus. Zg oda i porozumienie w zakresie akceptacji dla przestrzegania podstawowych wartości wynikających z praw człowieka, praw pracowniczych, wspomagane skutecznym wdrażaniem zasad CSR (corporate social responsibility - społeczna odpowiedzialność biznesu), mogą stać się punktem wyjścia do zacieśnienia więzi międzyspołecznych i być trwałą siłą wiążącą procesu integracji europejskiej. W związku z tym rodzą się pytania: czy i jak jest to możliwe?

\section{Trochę historii}

Koncepcja corporate social responsibility budzi wiele kontrowersji i nieporozumień. Jeśli sięgnąć do historii, zalążki problemów mieszczących się w obrębie późniejszej koncepcji społecznie odpowiedzialnego biznesu, pojawiły się w książce The Gospel of Wealth (1889) A. Carnegie 'go. Autor, rozpatrując kwestię zachowań etycznych w obszarze biznesu, społeczną odpowiedzialność przedsiębiorstw oparł na fundamentach biblijnych, wskazując dwa modele interpretacji, wedle których można rozpatrywać działalność ekonomiczną człowieka. Są nimi: dobroczynność (charity) i powierniczość (stewardship) (Rybak 2004, s. 15). Nieco później, w 1926 roku ukazała się książka Everetta Lorda The Fundamentals of Business Ethics. O coraz większym znaczeniu zasad CSR świadczy dobór treści programowych na uczelniach ekonomicznych. Przedmiot „etyka w biznesie” jest odrębną dyscypliną, ok. 80\% uczelni ekonomicznych wprowadziło go do programu studiów. Wiele nieprawdziwych informacji dotyczących zasad CSR pojawiło się na skutek uproszczonych interpretacji. Obiegowe opinie sugerują, że gdy mówi się o CSR, tak naprawdę mamy do czynienia z działalnością charytatywną lub sponsoringiem, co jest dalekie od prawdy. Inny głos dotyczy twierdzenia, że jedyną formą, jakiej możemy wymagać od biznesu, jest odpowiedzialność menedżerów wobec kapitałodawców. Tego zdania jest Milton Friedman. Korporację powołuje się do istnienia w celu maksymalizacji zysków, a oczekiwać od niej odpowiedzialności wobec społeczeństwa, to wyręczać w działaniach rząd, do czego biznesman-menadżer nie ma legitymizacji ani kompetencji. Głównym zadaniem kadry menedżerskiej jest jak najlepsze z ekonomicznego punktu widzenia zarządzanie firmą. Menedżerowie więc powinni być odpowiedzialni przede wszystkim wobec akcjonariuszy, swoich pracodawców (Friedman 1999, s. 260-265).

Również wśród stanowisk, tłumaczących fenomen dobrowolnej strategii zarządzania firmą i personelem, opartych na przestrzeganiu zasad etycznych zachodzą znaczące różnice. Warto przywołać kilka opinii na ten temat. Rozumienie etyki w biznesie jako metody walki z konkurencjąjest lansowane przez Gillesa Lipovetsky`ego. Zwraca on uwagę na elastyczność w doborze środków, mających przyczynić się do skuteczniejszej konkurencyjności przedsiębiorstw. Etyka jest dlań jednym z narzędzi służących doraźnym celom rynkowym: „W nowych 
warunkach światowej konkurencji, charakteryzującej się niestabilnością, szybkością cykli produkcyjnych i wstrząsami popytu, konkurencyjność firmy wymaga elastyczności i jasności, co nie daje się już pogodzić z hierarchicznym i autorytarnym sposobem kierowania" (Lipovetsky1998). Peter Pratley twierdzi, że etyka biznesu przyczyniła się do zmian w sposobie życia, dlatego refleksja moralna $\mathrm{w}$ obrębie świata biznesu jest traktowana przez niego jako czynnik kulturotwórczy (Pratley 1998, s. XIV). Zgoła odmienny pogląd reprezentuje francuski autor Alain Etchegoyen (Etchegoyen 1991). Jego zdaniem, etyka gospodarcza stanowi zasłonę, za którą skrywa się ze swej natury nieetyczny biznes, co wskazuje na fakt erozji w sferze moralnej społeczeństw oraz utratę orientacji na wartości we współczesnym świecie (Filek 2004, s. 10).

Należy też poruszyć szalenie istotny problem metodologiczny, który pojawia się wskutek podejmowania prób połączenia odmiennych dyscyplin naukowych: ekonomii i etyki, mianowicie jak możliwe jest pogodzenie ekonomii z etyką (Boulding 1985). Jak powszechnie wiadomo, działanie etyczne wymaga od podmiotu jako sprawcy czynu pobudki czysto moralnej. Wymiar ekonomiczny ujawnia nam działanie tegoż podmiotu, kierującego się głównie własnym interesem. W literaturze przedmiotu pojawiają się głosy, że to karkołomne połączenie obu obcych sobie dziedzin wskazuje na błąd logiczny contradictio in terminis ${ }^{2}$. Czy obie dyscypliny da się więc pogodzić? Normy moralne, obowiązując bezwarunkowo, wyznaczają kierunek działań człowieka uzgadniającego je z własnym pojęciem człowieczeństwa. Na decyzje człowieka wpływają także normy ekonomiczne, które nie tak radykalnie, bo warunkowo, regulują jego postępowanie w przestrzeni życia gospodarczego. Ale człowiek własne zachowania $\mathrm{w}$ przestrzeni życia gospodarczego może uzgadniać z zasadami etycznymi, co wcale nie musi prowadzić do sprzeczności. Chcąc osiagnąć materialnie wyższy poziom życia, może kierować się przyjętymi zasadami etycznymi i uzgadniać je z zasadami ekonomii. W tym przypadku problemem podstawowym jest pierwszeństwo zasad, wedle których będzie chciał postępować (Galata 2007, s. 120). Z tego też względu warto wskazać na dwa modele, jakie dla określenia społecznej odpowiedzialności przyjął A.B. Carroll.

Jednym z nich jest model before profit obligation. Podstawą do jego tworzenia jest uznanie pierwszeństwa wartości moralnych przed innymi. Każda korporacja jest zobowiązana do przestrzegania zakazów i nakazów moralnych oraz społecznych na każdym etapie swej działalności. Nie dopiero wtedy, gdy osiagnie wymagany zysk. Osiagnięty poziom zysku bez przestrzegania istniejących norm nie ma moralnej legitymizacji i nie jest usankcjonowany etycznie, wedle zasad CSR nie posiada wartości. Dlatego postulat, aby przedsiębiorstwa podlegały zewnętrznemu audytowi i aby wypracowano skuteczne mechanizmy kontroli społecznej, staje się niezbędny. Wnioski można przedstawić następująco: podstawą dla CSR jest przede wszystkim moralna odpowiedzialność indywidualnych osób. Odpowiedzialność dotyczy wszelkich decyzji i działań, za którymi stoją pojedyncze osoby³. Członkowie zarządów,

${ }^{2}$ Łac.: 'sprzeczność w określeniu, pojęciach, terminach'. Błąd logiczny, gdzie każdy z dwóch składników wyrażenia logicznego jest zaprzeczeniem drugiego lub neguje drugie, np. mały olbrzym etc.

${ }^{3} \mathrm{Za}$ W. Gasparskim należy zwrócić uwagę, że „Etyka wszelkiego rodzaju działalności ludzkiej, tym bardziej działalności zawodowej, składa się z dwu działów [Bunge, 1988, 255 i nast.]: działu zwanego endomoralnością, dotyczącego kwestii wewnętrznych rozpatrywanego rodzaju działań, tj. norm moralnych (kodeksu) danego rodzaju działalności, działu zwanego egzomoralnością, dotyczącego kwestii zewnętrznych rozpatrywanego rodzaju działań, tj. norm moralnych (kodeksu) dotyczących społecznej odpowiedzialności związanej z uprawianiem danego rodzaju działalności. Przez kodeks moralny rozumie się powyżej katalog norm etycznych - utrwalony choć niekoniecznie spisany - jakich należy przestrzegać uprawiając dany rodzaj działalności. W działalności gospodarczej endomoralność dotyczy reguł funkcjonowania biznesu, egzomoralność zaś dotyczy społecznej odpowiedzialności systemu gospodarczego zarówno jako całości, jak i poszczególnych przejawów aktywności składowych tego systemu" (Gasparski, www.cebi.pl, dostęp: 11.11.2010). 
menedżerowie firm i korporacji, dokonując wyborów przy podejmowaniu decyzji ekonomicznych, powinni bezwzględnie przestrzegać norm prawnych, norm etyczno-moralnych i społecznych. Działalność biznesu oparta na wyborze rzeczywistych wartości, buduje model before profit obligation, zadając kłam obiegowym opiniom, że na CSR stać tylko najbogatszych.

Model drugi to after profit obligation, w którym Carroll wyróżnia cztery stopnie odpowiedzialności przedsiębiorstwa: wymaganą przez społeczeństwo odpowiedzialność ekonomiczna, prawną, oczekiwaną przez społeczeństwo odpowiedzialność etyczną, i pożądaną odpowiedzialność filantropijną. Odpowiedzialność ekonomiczna odnosi się do zyskowności i wymaga, aby wszelkimi sposobami ograniczać straty. Postulat ekonomiczności jest traktowany nadrzędnie wobec innych, ponieważ wpierają się na niej pozostałe formy odpowiedzialności społecznej. A.B. Carroll twierdzi, że gdy zakwestionujemy tę formę odpowiedzialności jako najważniejszą, problem odpowiedzialności społecznej stanie się bezcelowy.

Wyżej na szczeblu odpowiedzialności sytuuje się odpowiedzialność etyczna, która oznacza konieczność działania w sposób sprawiedliwy w obszarze wolnym od regulacji prawnych. Poziom odpowiedzialności moralnej zależy od stopnia wrażliwości społeczeństwa na wartości etyczne, m.in. na sprawiedliwość i godziwość zachowań. Najważniejszą pozostaje wciąż etyka podmiotu, czyli etyka osoby podejmującej decyzje oraz odpowiadającej za działalność przedsiębiorstwa. Czynnikiem decydującym o zakresie i poziomie odpowiedzialności społecznej przedsiębiorstwa jest więc poziom etyczny społeczeństwa, a także coś, co można określić mianem sumienia menadżerów i pracowników. Elementem wspomagającym podejmowanie przez nich decyzji są kodeksy etyczne przedsiębiorstwa. Wszystkie razem stanowią zewnętrzne i wewnętrzne czynniki wywierające wpływ na poziom etyczny firmy.

Wierzchołek w modelu after profit obligation zajmuje odpowiedzialność filantropijna. Czyni z korporacji instytucję obywatelską, przeznaczając część zasobów przedsiębiorstwa (środki finansowe, czas pracowników etc.) na rzecz społeczeństwa. Działalność firmy w tym obszarze ma na celu udzielanie konkretnej pomocy oraz wpływa na poprawę warunków życia, przyczyniając się do rozwiązywania problemów społecznych w sensie globalnym i lokalnym (Rybak 2004, s. 30-31). Tak czy inaczej, odpowiedzialność społeczna przedsiębiorstw nawet na etapie budowania swego wizerunku i pozycji na rynku powinna w swych decyzjach i działaniach uwzględniać potrzeby społeczne przy zachowaniu zasad etycznych i tych sankcjonowanych prawem. Uzgadnianie własnych działań wraz z potrzebami innych członków społeczeństwa, odnoszących się do takich sfer życia jak ekorozwój, dbałość o stopniowe zmniejszanie emisji zanieczyszczeń, jasna i przejrzysta polityka komunikacji, a także budowanie uczciwych relacji z interesariuszami zewnętrznymi i wewnętrznymi, które powinny się opierać na kompetencjach i aprobacie zrozumiałych dla pracowników kryteriów postępowania wobec kadry oraz personelu, wymaga od menedżerów uznania zasad, którymi firma ma się kierować. Powinno też zwrócić ich uwagę na potrzebę tworzenia kodeksu postępowania etycznego. Kodeks nie może być jednak jedynie zapisem, ale ma stanowić pomocny instrument w moralnie skomplikowanych sytuacjach, w których pracownik firmy w każdej chwili może się znaleźć.

\section{Co o CSR i CS warto wiedzieć}

Można zadać pytanie, czy i jakiego rodzaju zobowiązania mogą mieć firmy wobec społeczeństwa. Podobnie jak w modelu A.B. Carrolla, na czoło wysuwają się obowiązki ekonomiczne. Przedsiębiorstwa powstają po to, aby przynosiły zysk, oferując dobra i usługi na rzecz społeczeństwa. Dodać należy, że zbywane towary, na które istnieje zapotrzebowanie rynkowe, powinny mieć uczciwą cenę. Firma, prowadząc działalność produkcyjno-handlową jest zobowiązana do przestrzegania obowiązujących regulacji prawnych. W sensie etycznym muszą to 
być działania zgodne z przyjętymi normami społecznymi. Nikt nie może przymusić korporacji do działania filantropijnego, toteż tego typu działalność zyskuje kwalifikację czysto uznaniową, bowiem zależy w dużej mierze od indywidualnych wyborów, będących najczęściej inicjatywą właścicieli lub menedżerów.

Jeśliby szukać faktów, które dały asumpt do pogłębionej refleksji nad rozwojem zrównoważonego biznesu, należałoby wymienić globalizację, demokrację i rozwój nauki o zarządzaniu. W pierwszym przypadku, swobodny przepływ kapitału, wzrastający poziom inwestycji oraz ożywiona wymiana handlowa sprawiły, że korporacje zaczęły zarządzać etycznie, uzależniając wybory kontrahentów w łańcuchach dostaw od realizowania przez nich zasad CSR. Stawia się im określone wymagania. Do rozpowszechniania zasad społecznej odpowiedzialności biznesu przyczynił się szybki przepływ informacji. Nie do przecenienia jest tu rola internetu. Wymusza to na firmach przejrzystość działań, bowiem niczego nie da się ukryć. Grupy nacisku, skoncentrowane np. na ratowaniu i ochronie przyrody przez kampanie informacyjne lub tzw. bojkoty konsumenckie, są w stanie skutecznie wpłynąć na opinię publiczną, aby ta wykluczyła z rynku nieuczciwe firmy. Ponadto wzrost i podobny poziom konkurencyjności wymuszają na korporacjach działania zorientowane na wartości pozamaterialne. Od takich działań zależy ich reputacja i przyczyniają się one do wzrostu konkurencyjności na rynku. W tym wypadku połączenie corporate social responsibility oraz public relations może przynieść wymierne korzyści. Firmy coraz częściej starają się o uzyskanie certyfikatów jakości zarządzania, do których należy m.in. norma ISO 26000, wymieniająca obszary dla refleksji etycznej przedsiębiorstw starających się o uzyskanie certyfikacji. Należą do nich: ład organizacyjny firmy (Organisational Governancne), prawa człowieka (Human Rights), etyka w biznesie (Fair Operating Practices), środowisko (Environment), praktyki i aspekty pracownicze (Labour Practices), komunikacja i współpraca z klientami (Consumer Issues) oraz rozwój społeczny (Social Development). Każdy z tych obszarów dotyczy przyjętych wartości, do przestrzegania których zachęca norma ISO 26000. Obok ISO 26000 istnieje ISO 14001 (polskie oznaczenie normy pochodzące z 2005 roku to PN-EN ISO 14001:2005), standard odnoszący się do problemu ekozarządzania, pozwalający budować system zarządzania środowiskowego oparty na tzw. podejściu procesowym. Najważniejszym elementem, (podobnie jak w ISO 9001) jest ciągłe doskonalenie działań organizacji opartych na założeniach Williama Edwardsa Deminga, amerykańskiego specjalisty i statystyka pracującego w Japonii. Jego pomysłem jest cykl PDCA, zakładający cztery etapy działania: plan - planuj, do-wykonaj, check - sprawdź, act-działaj.

Definicji CSR jest wiele, ale warto przytoczyć przynajmniej dwie. Pierwsza z nich powiada, że CSR to koncepcja, wg której przedsiębiorstwa na etapie budowania strategii dobrowolnie uwzględniają interesy społeczne i ochronę środowiska, a także relacje z różnymi grupami interesariuszy. Bycie odpowiedzialnym nie oznacza spełnienia wszystkich wymogów formalnych i prawnych, ale także zwiększone inwestycje w zasoby ludzkie, ochronę środowiska i relacje $\mathrm{z}$ interesariuszami, czyli dobrowolne zaangażowanie. Społeczna odpowiedzialność jest procesem, w ramach którego przedsiębiorstwa zarządzają swoimi relacjami z interesariuszami, mogącymi mieć faktyczny wpływ na ich powodzenie w działalności gospodarczej (Mediaplanet 2008). Drugą z przytaczanych definicji opracowało Ministerstwo Pracy i Polityki Socjalnej. Mówi się w niej, że CSR jest to efektywna strategia zarządzania, która poprzez prowadzenie dialogu społecznego na poziomie lokalnym przyczynia się do wzrostu konkurencyjności przedsiębiorstw na poziomie globalnym i jednocześnie kształtowania warunków dla zrównoważonego rozwoju społecznego i ekonomicznego. Kategoria zrównoważonego rozwoju ma współcześnie coraz większe znaczenie. Warto zauważyć, że CSR jest coraz częściej pojmowany jako strategia zrównoważonego rozwoju. Jaka więc jest między nimi różnica? 
Zrównoważony rozwój (CS - corporate sustainability lub sustainability development) to proces obejmujący przemiany społeczne i gospodarcze, w którym - w celu równoważenia szans w dostępie do środowiska poszczególnych społeczeństw, zarówno współczesnego, jak i przyszłych pokoleń - następuje integrowanie działań politycznych, gospodarczych i społecznych przy zachowaniu równowagi przyrodniczej oraz trwałości procesów przyrodniczych.

\section{Standard ISO 26000}

Firmy chcące uzyskać certyfikat potwierdzający realizowanie przez przedsiębiorstwo najwyższych standardów etycznych powinny spełniać określone przez normę wymagania w kilku obszarach. Jednym z nich jest ład organizacyjny, gdzie stawia się wymagania w zakresie przestrzegania transparentności, otwartości i etycznego postępowania. Chodzi tu także o uwzględnianie roszczeń i potrzeb interesariuszy, a także o efektywne wykorzystywanie zasobów. W sensie etycznym, firma powinna równomiernie planować skład kadry nadzorczej, w którym część stanowisk powinny obejmować kobiety. Przy ocenie brany jest również pod uwagę udział pracowników w procesach decyzyjnych co do realizacji zasad CSR. Badania wykazują, że stopień udziału w tych procesach jest znacznie wyższy w firmach, w których przeważa kapitał zagraniczny. Rodzimi przedsiębiorcy decyzje podejmują najczęściej jednoosobowo. W firmach z kapitałem zagranicznym różne grupy interesariuszy, a wśród nich także pracownicy niższych szczebli, mają wpływ na decyzje dotyczące zakresu programów zaangażowania społecznego, podczas gdy w firmach z kapitałem krajowym najczęściej takie decyzje podejmuje Prezes (w firmach państwowych) lub właściciele (w firmach będących własnością prywatnego kapitału krajowego) (Rok, 2009). Do zadań nakreślonych przez normę ISO 26000 należy precyzyjność zakresu odpowiedzialności podmiotu gospodarczego w sensie pozytywnych i negatywnych rezultatów jego działań. Korzyści, jakie firma może wynieść z praktyk w zakresie procesu podejmowania decyzji w organizacji jest kilka. Dysponowanie szerszą wiedzą pozwalającą na podejmowanie trafniejszych decyzji w przyszłości to jedna z nich, inna dotyczy dobrych relacji podmiotu w interesariuszami oraz społecznością lokalną. Poprawne kontakty pozwalają na zwiększenie zaufania do organizacji i lepsze zrozumienie profilu jej działalności.

Kolejny obszar objęty standaryzacją ISO 26000 odnosi się do praw człowieka. Pod tym pojęciem rozumie się wszystkie niezbywalne prawa, jakie przysługują człowiekowi na mocy jego istnienia jako osoby, której inherentnie przynależna jest godność. Chodzi zwłaszcza o gwarancję praw pracowniczych, tj. m.in. zagwarantowanie pracownikom prawa do wolnego zrzeszania się (związki zawodowe) we wszelkie układy zbiorowe. Problemem mocno obecnym w tym obszarze są kwestie pracy przymusowej, czyli pracy nieletnich, a także formy dyskryminacji w środowisku pracy ze względu na stopień niepełnosprawności, wiek, płeć, wyznanie, światopogląd czy orientację seksualną. Firma, która nie przestrzega standardów etycznych w zakresie praw człowieka, w oczach interesariuszy szybko traci reputację, co skutkuje najczęściej utratą zaufania publicznego, niezbędnego dla działalności ekonomicznej.

Wpływ działań przedsiębiorstwa na środowisko naturalne to kolejna dziedzina w ramach normy ISO. Ekorozwój firm dotyczy przede wszystkim troski o ograniczone zużycie surowców i energii, a także stałej troski o ograniczanie odpadów i zanieczyszczeń emitowanych do atmosfery. Emisja gazów cieplarnianych, o której robi się coraz głośniej, jest związana ze zmianami klimatycznymi, niekorzystnie wpływającymi zarówno na troposferę, jak i stratosferę, która mieści warstwę ozonową. Firmy są odpowiedzialne za ochronę naturalnych ekosystemów i zachęcane do uwzględniania założeń środowiskowych już na początku procesu produkcji. Przestrzeganie zaleceń w tym obszarze przyczynia się do zwiększenia oszczędności, 
szczególnie w zakresie obniżenia zużycia wody, odzyskiwania surowców, zmniejszenia materiałochłonności i wydatkowania na energię.

Norma ISO 26000 zwraca uwage na relacje z własnymi pracownikami przedsiębiorstwa oraz konsumentami. Problem ten w znacznej mierze odnosi się do jakości zarządzania kapitałem ludzkim. Zarządzanie powinno iść w stronę unikania sezonowych wahań w poziomie zatrudnienia. Istotną kwestią jest eliminacja przejawów dyskryminacji oraz wiedza na temat zawierania umów z kontrahentami. Powinni oni gwarantować najwyższe standardy etyczne przy zatrudnianiu pracowników. Pomocnym instrumentem w tej dziedzinie są kodeksy postępowania etycznego, które jeśli są przestrzegane przez wszystkich pracujących, skutecznie eliminują niewłaściwe relacje pomiędzy pracodawcą a pracownikiem, a także pomiędzy samymi pracownikami różnego szczebla. W relacjach z konsumentami chodzi o tzw. uczciwy marketing, opierający się na dostępie do rzetelnej informacji o produkcie oraz przestrzeganiu zasad uczciwości podczas zawierania umów. Działania dotyczą także sposobów permanentnego procesu usprawnień technologicznych, co winno być podyktowane troską producenta o zmniejszenie ryzyka i niepożądanych skutków użytkowania niektórych wyrobów. W skład zagadnień w tym obszarze wchodzi również problem serwisowania produktów. Zaangażowanie społeczne i rozwój to sfera refleksji podmiotów gospodarczych, w której na pierwszy plan wysuwają się działania mające na celu skuteczne zmniejszanie nierówności społecznej, ubóstwa i głodu na świecie. Ich zakres dotyczy w równej mierze przedsięwzięć o charakterze globalnym, jak i lokalnym, a w ich ramach promuje się inicjatywy zmierzające do upowszechnienia nauczania oraz zwiększania dostępności ofert edukacyjnych kierowanych do każdej z grup społecznych, szczególnie warstw o najniższym wskaźniku dochodów.

Wymienione działania służą wzmocnieniu fundamentów demokracji i sprzyjają tworzeniu podstaw dla rozwoju społeczeństw obywatelskich. Są one wspierane przez funkcjonujące i powstające instytucje, których zadaniem jest podnoszenie czynnika spójności i stabilności społeczno-gospodarczej. W tym obszarze firmy często nawiązują kontakty z innymi organizacjami, prowadzącymi lub wspierającymi inicjatywy na rzecz społecznej odpowiedzialności. W ramach tego typu relacji partnerskich przeprowadza się inwestycje społeczne zgodne z działalnością firm. Połączone podmioty gospodarcze zwiększają tym samym skuteczność swoich działań, angażując w nie różne organizacje pozarządowe.

Na koniec należy wspomnieć o jeszcze jednym ważnym elemencie działalności gospodarczej, nakierowanym na realizację uczciwych praktyk rynkowych. Chodzi o eliminowanie z życia gospodarczego zachowań społecznie niepożądanych, do których zalicza się m.in. korupcję. Działalność firmy jest tu zorientowana na skuteczne ograniczenie zjawiska prania brudnych pieniędzy. Zadaniem tych przedsięwzięć jest więc budowanie przyjaznych warunków dla funkcjonowania otoczenia społecznego i ekonomicznego, pozwalającego na przejrzystą politykę firmy i inicjowanie poprawnych relacji z najbliższymi interesariuszami przedsiębiorstwa.

\section{Agendy i organizacje wpierające i propagujące CSR}

Najważniejszym programem wspierającym CSR jest Global Compact (GC). Powstał on z inicjatywy Sekretarza Generalnego ONZ, Kofiego Annana, i został ogłoszony w 2000 roku. Annan zaapelował do świata biznesu, aby przedsiębiorstwa w swych działaniach kierowały się dziesięcioma podstawowymi zasadami, do których należą prawa człowieka, prawa pracownicze, dyrektywy odnoszące się do ochrony środowiska, przeciwdziałanie korupcji. Global Compact, promując społeczną odpowiedzialność biznesu, swą sieć rozwinął wokół Biura GC i sześciu agend ONZ: Międzynarodowej Organizacji Pracy, Biura Wysokiego Komisarza ds. Praw Człowieka, Programu Narodów Zjednoczonych ds. Ochrony Środowiska, Programu 
Narodów Zjednoczonych ds. Rozwoju, Organizacji Rozwoju Przemysłu ONZ i Biura ONZ ds. Kontroli Narkotyków i Zapobiegania Przestępczości. Na apel przewodniczącego odpowiedziało ponad pięć tysięcy firm, organizacji i interesariuszy z ponad stu dwudziestu krajów, które działają w sześćdziesięciu sieciach lokalnych. W Polsce Global Compact jest obecny od 2001 roku, a działania oparte na GC są wspierane przez polski oddział Programu Narodów Zjednoczonych ds. Rozwoju UNDP.

Obok GC istnieje CSR Europe. To europejska sieć biznesu na rzecz CSR stworzona w 1995 roku przez europejskich menedżerów i liderów biznesu. Powołanie jej do życia było skutkiem apelu, tym razem Przewodniczącego Komisji Europejskiej - Jacquesa Delorsa. CSR Europe to niemal osiemdziesiąt korporacji i dwadzieścia pięć organizacji partnerskich z dwudziestu dwóch krajów. Przesłaniem sieci jest wspieranie firm członkowskich w procesie integracji działań CSR z codziennym prowadzeniem biznesu.

Kolejnym podmiotem, którego zadaniem jest upowszechnienie zasad społecznej odpowiedzialności biznesu, jest The European Alliance For CSR, czyli Europejski Sojusz na rzecz CSR. Działalność tej organizacji opiera się na otwartym partnerstwie dużych i małych firm w Europie wraz z grupą ich interesariuszy. Jej członkowie działają na rzecz innowacyjnych i odpowiedzialnych praktyk biznesu. Sojusz powstał w marcu 2006 roku przy mocnym wsparciu Komisji Europejskiej. Do działań koordynujących i obsługi Komisja wybrała CSR Europe, Business Europe i UEAPME (European Association of Craft, Small And Medium-Sized Enterprises). Wymieniony sojusz to polityczne ciało działające na rzecz mobilizacji zasobów dużych i małych przedsiębiorstw i ich interesariuszy zorientowanych na realizację dziesięciu priorytetów. Należą do nich m.in.: innowacyjność i przedsiębiorczość w zrównoważonych technologiach, produktach i usługach odpowiadające społecznym potrzebom oraz stosowanie unijnych standardów społecznej i środowiskowej odpowiedzialności w działalności poza Unią Europejską.

Również w Polsce istnieją organizacje wspierające programy oparte na koncepcji społecznej odpowiedzialności biznesu. Jedna z najbardziej znanych to Stowarzyszenie Akademia Rozwoju Filantropii w Polsce, będące organizacją pozarządową typu non-profit. Działa ono od 1998 w sześciu obszarach programowych: rozwoju społeczności lokalnych, aktywności młodzieży i osób starszych, społecznie zaangażowanego biznesu, przedsiębiorczości społecznej, filantropii indywidualnej. Prowadzi ono konkurs „Dobroczyńca Roku”. Inną polską organizacją, skupiającą pracodawców, jest PKPP Lewiatan. Przy współpracy z Centrum Etyki Biznesu (CEBI) opracowała ona Kanon Etyczny Przedsiębiorców, który jest wiążącą deklaracją wartości odpowiedzialnego biznesu, realizowanego przez podmioty stowarzyszone w PKPP Lewiatan.

Fundacja Instytut Badań nad Demokracją i Przedsiębiorstwem Prywatnym to z kolei niezależny i niedziałający dla zysku ośrodek think tank, zajmujący się badaniami i analizami kwestii publicznych. Do celów działalności tego typu ośrodków należy zazwyczaj poszukiwanie sposobów rozwiązania problemów społecznych i udział w publicznej debacie Krajowej Izby Gospodarczej. Fundacja Instytut Badań nad Demokracją i Przedsiębiorstwem Prywatnym działa od 1993 roku, zaś naczelnym projektem instytutu jest „Zatrudnienie Fair Play”. Ośrodek realizuje program „Przedsiębiorstwo Fair Play”, przyznając w tej dziedzinie certyfikaty.

Innym podmiotem wspierającym działania w ramach CSR w Polsce jest Forum Odpowiedzialnego Biznesu (FOB). To organizacja pozarządowa, zajmująca się od 2002 roku koncepcją społecznej odpowiedzialności biznesu. Posiada status narodowej organizacji partnerskiej CSR Europe. W ramach swej działalności, FOB opracował program edukacyjny Liga Odpowiedzialnego Biznesu, którego zadaniem jest budowa nowych kadr menedżerów i przedsiębiorców, mających być animatorami społecznymi i liderami zmian w zakresie odpowiedzialności. 
Ciekawą inicjatywą jest Instytut Partnerstwa Biznesu i Organizacji Pozarządowych Bi-Ngo, powstały w 2007 roku przy Wydziale Zarządzania Uniwersytetu Łódzkiego. Instytut zajmuje się upowszechnianiem wzorców współpracy biznesu i organizacji pozarządowych, które mają służyć rozwiązywaniu problemów społecznych i dbałości o zrównoważony rozwój ekonomiczno-społeczny na poziomie ogólnokrajowym i lokalnym. Inicjatywa CSRinfo powstała, by budować i dzielić się wiedzą z zakresu społecznej odpowiedzialności biznesu i zrównoważonego rozwoju. W ramach działalności CSRinfo powstał portal informacyjny na temat społecznej odpowiedzialności przedsiębiorstw. Na rzecz upowszechnienia programów CSR działają też Centrum CSR.PL i Centrum Etyki Biznesu (CEBI).

Najbardziej znaną w Polsce jest organizacja skupiająca liderów biznesu Business Center Club. Ta jednocześnie największa polska organizacja indywidualnych pracodawców powstała jako instytucja wielopłaszczyznowa. Do jej głównych zadań należy wspieranie przedsiębiorczości. W ramach działań organizowane są seminaria na tematy związane z CSR, prowadzona jest też akcja społeczna pt. „Podziel się sukcesem”.

\section{Kierunki CSR i komunikacja}

Kierunki rozwoju firm, chcących oprzeć swą działalność na zasadach CSR, zostały wyznaczone przede wszystkim przez organizacje międzynarodowe, do których należą ONZ, OECD czy UE. Wszystkie one wywierają ogromny wpływ na działalność firm w różnych krajach. Warto wspomnieć choćby o kryteriach wyboru korporacji współpracujących, jakiego dokonuje się w oparciu o zrównoważone zamówienia. W przypadku zamówień publicznych kryterium ceny nie musi być najważniejszym. O wiele bardziej docenia się np. realizowane przez kontrahentów standardy dotyczące ochrony środowiska naturalnego, gdzie przy zawieraniu umów i transakcji analizuje się konkretne przedsięwzięcia firmy w zakresie ograniczenia zanieczyszczeń, budowy oczyszczalni ścieków lub wysokość nakładów na ograniczenie produkcji uciążliwej dla otoczenia. Przedsiębiorstwa z dużym potencjałem finansowym mogą oczekiwać, że opinia publiczna będzie się domagać skrupulatnych raportów, w których firma będzie musiała rozliczyć się ze środków przeznaczonych na inwestycje zabezpieczające lub ograniczające jej destrukcyjny wpływ na otoczenie, w którym prowadzi działalność gospodarczą.

Do najbardziej rozpowszechnionych standardów komunikowania osiągnięć w zakresie przyjętych strategii opartych na CSR należy Global Reporting Initiative (GRI). Wskaźniki GRI nie są jednolite dla każdej branży. Przedsiębiorstwa opracowujące raporty oparte na wskaźnikach GRI są umieszczane w bazach danych na stronie internetowej GRI (www.globalreporting.org). Obok nazwy firmy wymienia się także zakres, w jakim podmiot zastosował wytyczne GRI.

Działania w zakresie CSR należy komunikować interesariuszom. Obszar problemów dotyczy takich zagadnień jak: misja i wizja firmy, tożsamość moralna firmy ${ }^{4}$, przyznane nagrody i zdobywane certyfikaty jakości, terminowość regulowania zobowiązań, współpraca w regionie, opinie zadowolonych interesariuszy (klientów), pozytywne diagnozy i wyniki testów

\footnotetext{
${ }^{4}$ Przez pojęcie „tożsamość moralna firmy” należy rozumieć możliwość przypisania przedsiębiorstwu pewnych intencji, z których wypływa domniemanie o jego zdolności jako osoby prawnej do ponoszenia odpowiedzialności moralnej. Zwolennicy tego stanowiska kierują się założeniem, że istnieje (da się ją wskazać) szczególna intencja funkcjonowania firmy, będąca czymś więcej niż tylko sumą intencji działań indywidualnych. Zakłada się więc pewien nadrzędny, łączący w spójną całość, poziom ,intencji przedsiębiorstwa". Poziom ten, istniejąc niezależnie od indywidualnych preferencji menedżerów, pozwala kierować indywidualnymi intencjami nawet wtedy, kiedy nastąpi wymiana zatrudnionych osób. Działania oparte na wymienionych wyżej elementach składowych kreują w szczególny sposób tożsamość moralną korporacji, z którą związane są jej zobowiązania moralne.
} 
o produktach wprowadzanych przez firmę na rynek, a także informacje z zakresu bezpieczeństwa i higieny pracy, doniesienia o szkoleniach, sponsorowaniu instytucji lub inicjatyw w regionie. Ważną kwestią jest też informacja o działaniach w zakresie wolontariatu i osiaganiu wymiernych korzyści dzięki realizacji inicjatyw w ramach CSR (Gasiński, Piskalski 2009, s. 30).

Ostatnio upowszechniła się praktyka dobrowolnego wypracowywania stanowisk w odniesieniu do ustaleń branżowych. Pozwalają one na stosowanie zasad benchmarkingu. Warto podkreślić, że dzisiejsze społeczeństwa są coraz bardziej wymagające. Do tego faktu przyczyniła się zwiększona świadomość oraz znaczne podniesienie stopy życiowej. Dziś nie tylko cena towaru interesuje klienta, równie ważna jest wiedza o charakterze peryferyjnym. Konsument zachodni, bardziej świadomy i wyczulony na kwestie związane z ochroną środowiska, docieka, skąd pochodzi surowiec, z którego produkowany jest towar, z jakich państw pochodzą półfabrykaty, kim jest producent, jaką ma opinię na rynku i wśród konsumentów itd. Może nas dziwić dociekliwość grup konsumenckich, ale z powodu nagłośnienia i upowszechnienia zasad CSR również rodzimi klienci coraz baczniej zwracają uwagę na te czynniki. Decyzji o zakupie tego lub innego produktu towarzyszy szereg pytań. To sukces grup wspierających inicjatywy CSR w Polsce.

Nieco gorzej wygląda sama realizacja zasad CSR przez firmy z przewagą kapitału krajowego. To teren do zagospodarowania, szczególnie w sytuacji, gdy mamy do czynienia z podobnym stanem konkurencyjności przedsiębiorstw. Realizacja strategii opartej na zasadach CSR staje się dlań szansą na osiągnięcie przewagi w zakresie konkurencyjności. Sprzyja temu proces integracji europejskiej, pozwalający na przenikanie się informacji oraz podpatrywanie (uczenie się) najlepszych wzorców, wedle których prowadzi się firmy na zachodzie Europy: „Inspiracją do poszukiwań najlepszych rozwiązań z zakresu społecznej odpowiedzialności dla przedsiębiorstw działających w Polsce są przede wszystkim programy realizowane w różnej skali przez przedsiębiorstwa funkcjonujące od dawna w Unii Europejskiej, a także oczekiwania w stosunku do sektora przedsiębiorstw w Polsce, związane z ich rosnącym udziałem w rynku europejskim, formułowane przez partnerów handlowych i organizacje branżowe w państwa Unii. Stosunkowo niewielka znajomość w Polsce światowych tendencji w zakresie społecznej odpowiedzialności, a jednocześnie konieczność poszukiwania nowych możliwości zdobywania przewagi strategicznej, stwarza niezagospodarowaną jeszcze przestrzeń dla wypracowania najlepszych strategii i standardów postępowania wobec akcjonariuszy, pracowników, konsumentów, dostawców czy przedstawicieli społeczności lokalnej oraz środowiska przyrodniczego" (Rok 2009).

\section{Przykłady praktyk CSR}

Warto posłużyć się kilkoma przykładami ilustrującymi konkretne działania w ramach CSR. Wymienione poniżej firmy, stosujące rozwiązania w zakresie społecznej odpowiedzialności biznesu, należą do najbardziej znanych. Wszystkie wymienione przykłady pochodzą z dodatku do „Gazety Prawnej” z 17 grudnia 2008 i zostały zamieszczone w broszurze pod tytułem Kompendium CSR. 


\section{Ile zarabia na Tobie bank?}

W ramach praktyk CSR znajduje się rzetelne informowanie klienta o swoim produkcie. Okazuje się, że szczerość popłaca. Hiszpański bank Caja Navarra wprowadził projekt, dzięki któremu klienci mogą na stronie internetowej sprawdzić indywidualnie, ile dokładnie zarabia na nich bank, a następnie przekazać część zysku na wybraną organizację charytatywną. W 2007 roku klienci Caja Navarra przeznaczyli w imieniu Banku na pomoc społeczną 47 mln euro. Jednocześnie bank zyskał 32 tysiące nowych klientów oraz osiagną $99 \%$ satysfakcji konsumenckiej.

\section{Zdrowe odżywianie}

Grupa Casino postanowiła zająć się działaniem w obszarze zdrowego żywienia. Jako że problemem XXI wieku staje się otyłość spowodowana głównie niewłaściwymi nawykami żywieniowymi, firma postanowiła zadbać o edukację swoich klientów. Grupa Casino zamieszcza na produktach dokładne informacje dotyczące składu i wartości odżywczych oraz wydała podręcznik zdrowego żywienia w nakładzie 500 tysięcy egzemplarzy. W ten sposób zyskuje grupę świadomych, darzących ją zaufaniem klientów i jednocześnie działa w skali globalnej, edukując konsumentów.

\section{Bankowość internetowa dla niewidzących}

Polski oddział banku Nordea postanowił wprowadzić ułatwienia w korzystaniu z serwisu internetowego osobom niewidzącym. Dzięki wykorzystaniu systemu głosowego osoba niepełnosprawna ma dostęp do swojego konta on-line i jednocześnie z pewnością staje się wierniejszym klientem instytucji finansowej. Działania Nordea są pierwszymi w tym zakresie w Polsce i Europie.

\section{Inteligentne oczy}

Grecka firma Cosmote Mobile Telecommunications And Microsoft Hellas zaproponowała nowinkę techniczną, mającą na celu ułatwianie poruszania się osobom niewidomym. Telefon komórkowy Smart Eyes został wyposażony w GPS i system głosowy. Niepełnosprawny może zadawać urządzeniu pytania (np. powiedzieć nazwę ulicy, gdzie chce trafić, nazwisko osoby, do której chce zadzwonić, nazwę instytucji, do której chce dotrzeć) i otrzymuje głosowe instrukcje.

\section{Mapa klimatu świata}

Grupa Vattenlall przeznaczyła środki na stworzenie mapy klimatu świata w 2030 roku. Dzięki opracowaniu otrzymujemy szczegółowe dane na temat zmian, jakie mogą zajść w środowisku, jeśli nie zostaną podjęte konkretne działania, głównie na rzecz zmniejszenia emisji CO2. Obliczono, że trzeba i można zredukować ową emisję o 27 gigaton do 2030 roku. Między innymi w ten sposób grupa działa na rzecz ochrony środowiska i podniesienia poziomu wiedzy.

\section{Napój bezalkoholowy dla kierowcy}

Akcje CSR w międzynarodowych korporacjach mogą być prowadzone oddzielnie przez jednostki w danych krajach. Irlandzki zespół Coca-Coli wprowadził ciekawe działanie mające na celu ograniczenie liczby pijanych kierowców na drodze oraz służące promocji napojów grupy. W wybranych barach Irlandii osoba prowadząca samochód i odwożąca towarzyszy zabawy do domu otrzymywała gratis darmowy napój.

\section{Rolnik z telefonem}

Firma BT (działająca w sektorze telekomunikacyjnym) wraz z organizacją charytatywną Oneworld postanowiła wspomóc informacjami na temat sposobu uprawiania ziemi hinduskich rolników. Dzięki specjalnemu systemowi opartemu na infolinii i specjalnych kioskach telekomunikacyjnych postawionych we wsiach, specjaliści odpowiadają na pytania zainteresowanych. W efekcie BT rozwija swój rynek w Indiach oraz działa na rzecz polepszenia poziomu życia - być może swoich przyszłych klientów.

\section{Praca dla każdego}

W ramach wyrównywania szans Volkswagen postanowił zaopiekować się niepełnosprawnymi i chorymi pracownikami. Dział HR firmy zapoznaje się z problemami tej grupy, a następnie wprowadza spersonalizowane ułatwienia, dzięki którym pracownicy wciąż mogą być czynni zawodowo i nie muszą wracać na rynek pracy, celem poszukiwania posady dopasowanej do swoich możliwości. W ten sposób Volkswagen nie tylko ułatwił życie swoim pracownikom, ale wyszedł też naprzeciw potrzebom starzejącego się społeczeństwa Europy (Mediaplanet 2008). 


\section{Podsumowanie}

Przedstawione problemy dotyczące wdrażania zasad CSR stanowią szczególną troskę organizacji propagujących takie działania. Ale to na firmach, kapitałodawcach (właścicielach) i menedżerach spoczywa odpowiedzialność za ich podejmowanie lub zaniechanie. Przystąpienie przedsiębiorstwa do realizacji założeń opartych na CSR pozostaje wciąż dobrowolne. Nie miałoby głębszego sensu prawne narzucenie działań o charakterze społecznej odpowiedzialności biznesu, ponieważ zasadniczym powodem powstawania firm jest ich rentowność i maksymalizacja zysku.

Dobrowolność w realizowaniu praktyk w ramach CSR w żaden sposób nie ogranicza działań menedżerów, a raczej ukazuje im alternatywną perspektywę ukierunkowującą ich decyzje oraz działania na grupy interesariuszy, od których w znacznym stopniu zależy kondycja finansowa firmy. Ponadto zasady CSR moga przyczynić się do poprawy wizerunku przedsiębiorstwa w oczach szerokiej grupy podmiotów gospodarczych, wchodzących w różne relacje z przedsiębiorstwem, co samo w sobie jest opłacalne. Należy więc zdać sobie sprawę z faktu, że realizacja zasad CSR nie musi być postrzegana jako dodatkowy koszt, obciążający budżet przedsiębiorstwa, ale powinno się ją interpretować jako zwrotną inwestycję długoplanową. Poniesione nakłady mają szansę się zwrócić, pod warunkiem przestrzegania przez firmę uczciwych zasad, na których wspiera się CSR.

Wymienione w artykule organizacje stanowią potwierdzenie faktu, że działalność biznesu oparta na zasadach CSR nie jest wymysłem czy modą, ale na trwałe toruje sobie drogę w naszej przestrzeni ekonomicznej. Instytucje oraz idea CSR przyczyniają się w dużym stopniu do likwidacji problemów społecznych i są wyraźną oznaką powrotu do konkretnych wartości w sferze ekonomicznej. Ich wdrażanie może zarówno przynieść wymierne korzyści dla procesu integracji europejskiej, jak i przyczynić się do osiagnięcia porozumienia w kwestii uznania wartości etycznych za najbardziej pożądane dla budowania ładu i spójnej polityki społecznej państw należących do wspólnoty unijnej.

\section{Literatura}

1. Adamczyk J., 2008, Społeczna odpowiedzialność przedsiębiorstw. Teoria i praktyka, PWE.

2. Bauman Z., 2000, Globalizacja, przeł. E. Klekot, PIW, Warszawa.

3. Bunge, M., 1988, Treatise on Basic Philosophy, t. 8, Ethics, Reidel, Dordrecht.

4. Boulding K.E., 1985, Czy ekonomia jest niezbędna? [w:] Ponad ekonomiq, pod red. J. Grosfelda, PIW, Warszawa.

5. Filek J., 2004, Wprowadzenie do etyki biznesu, Kraków.

6. Friedman M., 1970, Społeczna odpowiedzialność biznesu to zwiększanie zysków [w:] Chryssides G.D., Kaler J.H., Wprowadzenie do etyki biznesu, 1999, przeł. H. Simbierowicz, Z. Wiankowska-Ładyka, PWN, Warszawa, s. 260-265.

7. Galata S., 2007, Biznes w przestrzeni etycznej. Motywy, metody, konsekwencje, DIFIN, Warszawa.

8. Gasiński T. \& Piskalski G., 2009, Zrównoważony biznes. Podręcznik dla matych i średnich przedsiębiorstw, http://www.centrumcsr.pl/pliki/Podr_CSR-pojedyncze-podglad.pdf (dostęp: 24.10.2009).

9. Gasparski W., Etyczność marketingu - marketingiem etyczności, źródło: www.cebi.pl (dostęp: 24. 10.2009).

10. Klimczak B., 1996, Etyka gospodarcza, WAE im. O.L., Wrocław.

11. Klimczak B. (A), 1997, Etyczne otoczenie rynku kapitałowego, WAE im. O.L., Wrocław.

12. Laszlo Ch., 2008, Firma zrównoważonego rozwoju, Studio Emka.

13. Lipovetsky G., 1998, Zarzqdzanie i etyka odpowiedzialności, „Znak”. 
14. „Mediaplanet. Niezależna publikacja Mediaplanet dystrybuowana wraz z „Gazetą Prawną” 17 grudnia 2008", Kompendium CSR.

15. Pratley P., 1998, Etyka w biznesie, przeł. M. Albigowski, Gebethner i Ska, Warszawa.

16. Rok B., Społeczna odpowiedzialność biznesu w kontekście przemian rynkowych, źródło: www.cebi.pl (dostęp: 25.10.2009).

17. Rybak M., 2004, Etyka menedżera - spoteczna odpowiedzialność przedsiębiorstwa, PWN, Warszawa.

18. Żemigała M., 2007, Społeczna odpowiedzialność przedsiębiorstwa, Wolters Kluwer.

\section{The Significance and Legitimacy of Corporate Social Responsibility in the Conditions of the European Integration Process}

The author of this article describes and analyses the problem of CSR (Corporate Social Responsibility and also Sustainable Development) as a strategy to run a business. The main problem concerns the possibilities of working out an agreement in order to recognize the common values shared by key member states of the EU.

Despite their different views, the author of this text has the opinion that a good place for an achievement of consensus in this matter is the business arena. It seems probable that business will be the most neutral field to achieve harmony in social issues during the European integration process. 